\title{
POTENTIAL OF BIOLOGICALLY ACTIVE PLANT OILS TO CONTROL MOSQUITO LARVAE (Culex pipiens, DIPTERA: CULICIDAE) FROM AN EGYPTIAN LOCALITY
}

\author{
Hanem Fathy KHATER(1) \& Afaf Abdel-Salam SHALABY(2)
}

\begin{abstract}
SUMMARY
The insecticidal effect of six commercially available plant oils was tested against $4^{\text {th }}$ larval instars of Culex pipiens. Larvae were originally collected from Meit El-Attar, Qalyubia Governorate, Egypt, and then reared in the laboratory until $\mathrm{F}_{1}$ generation. The LC50 values were 32.42, 47.17, 71.37, 83.36, 86.06, and $152.94 \mathrm{ppm}$ for fenugreek (Trigonella foenum-grecum), earth almond (Cyperus esculentus), mustard (Brassica compestris), olibanum (Boswellia serrata), rocket (Eruca sativa), and parsley (Carum ptroselinum), respectively. The tested oils altered some biological aspects of $C$. pipiens, for instance, developmental periods, pupation rates, and adult emergences. The lowest concentrations of olibanum and fenugreek oils caused remarkable prolongation of larval and pupal durations. Data also showed that the increase of concentrations was directly proportional to reduction in pupation rates and adult emergences. Remarkable decrease in pupation rate was achieved by mustard oil at 1000 ppm. Adult emergence was suppressed by earth almond and fenugreek oils at $25 \mathrm{ppm}$. In addition, the tested plant oils exhibited various morphological abnormalities on larvae, pupae, and adult stages. Consequently, fenugreek was the most potent oil and the major cause of malformation of both larval and pupal stages. Potency of the applied plant oils provided an excellent potential for controlling C. pipiens.
\end{abstract}

KEYWORDS: Culex pipiens; Larvicidal oils; Morphological abnormalities; Biological aspects; Egypt.

\section{INTRODUCTION}

The mosquito, Culex pipiens is a worldwide insect causing dreadful nuisance and transmitting many dangerous diseases. In Egypt, it is the main vector of filarial worm Wuchereria bancrofti ${ }^{21}$ as well as Rift valley fever virus ${ }^{5}$.

Mosquito control is becoming increasingly difficult in Egypt because of the emergence of resistance of $C$. pipiens to many insecticides ${ }^{27}$. Consequently, there is an urgent need to explore and utilize naturally occurring products for combating such vectors.

Many authors worldwide started large screening activity for using extracts of medicinal and herbaceous plants to control mosquitoes ${ }^{4,6,10,11,12}$.

Some plant extracts such as yellow rocket and black mustard ${ }^{24}$, and fenugreek ${ }^{10}$ expressed insecticidal effect against mosquitoes. We tested earth almond, olibanum, and parsley for the first time.

The botanical insecticides are generally pest-specific and are relatively harmless to non-target organisms including humans. They are biodegradable and harmless to the environment ${ }^{11}$. Accordingly, the application of easily degradable plant compounds is considered one of the safest methods of control of insect pests and vectors ${ }^{20,22,23}$.

The goal of this study was not only to test the insecticidal effect of six plant oils, readily available in Egypt for domestic use, to control $C$. pipiens, but also to find out the alteration of some biological aspects and the morphological aberrations, following treatment with sublethal concentrations of the tested oils.

\section{MATERIALS AND METHODS}

Larvae of Culex pipiens were collected from Meit El-Attar, Qalyubia Governorate, Egypt, then reared in the laboratory according to KHATER ${ }^{12}$ and $4^{\text {th }}$ larval instars from $\mathrm{F}_{1}$ generation were exposed to the applied oils.

Commercially available plant oils, obtained from El-Kaptain Company, were used. Such oils were fenugreek (Trigonella foenumgrecum), earth almond (Cyperus esculentus), rocket (Eruca sativa), parsley (Carum ptroselinum), mustard (Brassica compestris), and olibanum (Boswellia serrata).

(1) Parasitology Dep., Faculty of Veterinary Medicine, Benha University, Egypt.

(2) Research Institute of Medical Entomology, Egypt.

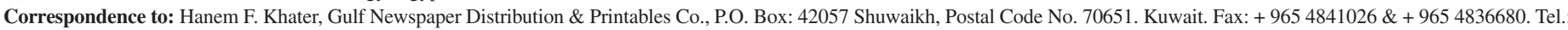
+ 965 7202755. E-mail: hafkhater@yahoo.com 
Test procedures were done according to WORLD HEALTH ORGANIZATION $^{26}$. Early $4^{\text {th }}$ larval instars of $C$. pipiens were exposed to six plant oils at 5-7 different concentrations, ranged from 7.81 to 2000 ppm. Moreover, tween 80 was used as an emulsifier. Each concentration of the tested oil together with an untreated control group were replicated four times, 15 larvae per replicate were transferred to $500 \mathrm{~mL}$ glass beaker containing $250 \mathrm{~mL}$ of dechlorenated water. Whereas, tween 80 was used in the control group. In the meantime, all the assays were repeated three times and done at $29 \pm 2{ }^{\circ} \mathrm{C}$ and $80 \pm$ $5 \% \mathrm{RH}$.

After starting the experiments, the larval mortality counts were determined daily until pupation. Accordingly, larvae were continuously exposed to the oils in order to determine the LC50 and LC90 values.

In order to determine the latent outcome of the used oils on some biological aspects, the number of developed pupae, for each concentration, was counted and the pupae were placed in a separate cage until the emergence of adults. Consequently, the developmental periods, pupation rates, and adult emergences were determined. During that time, the morphological abnormalities of larvae, pupae, and adults were recorded.

For statistical analysis, the mortality data were subjected to Probit analysis by computer (POLO-PCO) following FINNEY ${ }^{9}$. A Probit transformation was followed by regression analysis to determine the theoretical LC50 and LC90 values; whereas, the biological data were analyzed by Duncan's multiple range test via SPSS program.

\section{RESULTS}

All tested oils were effective against $4^{\text {th }}$ larval instars of $C$. pipiens, originally collected from Meit El-Attar, Qalyubia Governorate, Egypt. The calculated LC50 values were 32.42, 47.17, 71.37, 83.36, 86.06, and $152.94 \mathrm{ppm}$ for fenugreek, earth almond, mustard, olibanum, rocket, and parsley oils, respectively (Table 1). Such values indicated that fenugreek was the most effective oil, whereas parsley was the least toxic one. At the level of LC90s, the arrangement of such oils was changed as follows: earth almond, mustard, fenugreek, rocket, olibanum, and parsley.

Based on LC50 values of tested plant oils and that of parsley as a reference substance, the relative potency indicated that fenugreek, earth almond, mustard, olibanum, and rocket were 4.72, 3.24, 2.14, 1.83, and 1.48 times, respectively, more effective than parsley (Table 1).

As a consequence of larval treatments, some biological features were conspicuously varied, such as, developmental periods, pupation rates, and adult emergences (Tables 2 and 3). The larval and pupal durations were generally dose dependent relationships. Although the developmental periods of larvae and pupae was not affected by the lowest concentration of mustard and rocket oils, they produced significantly different changes of the durations from that of the control groups when higher concentrations were used. Beyond this point, the higher the concentration, the greater the effect of oils on larval developmental periods. Rocket, mustard, and parsley oils tended to shorten the duration of larvae when compared with that of the control group.

The developmental periods of larval and pupal stages were extremely prolonged after treatment with the lowest concentrations of olibanum and fenugreek. The longest larval and pupal periods were 14.9 and 8.2 days, respectively, after treatment of larvae with olibanum oil at $7.81 \mathrm{ppm}$. On contrary, earth almond and mustard oils decreased pupation periods. The effect was more pronounced with earth almond oil, whereas the pupal duration reached 0.5 days at $125 \mathrm{ppm}$.

The pupation rates and the adult emergences decreased as the concentration increased. Adult emergences were completely stopped by all applied oils when used at high concentrations. No adults were emerged following treatment with $125 \mathrm{ppm}$ of fenugreek and earth almond oils. Similar observations were recorded after exposure to 500 ppm of mustard, olibanum, and rocket oils.

Several forms of morphological malformations resulted from treatment of larvae with the applied oils. The larval abnormalities were pigmented and twisted larvae, as well as larval-pupal intermediates (pharate pupae). Whereas, the pupal and adult aberrations were albino, elephantoid, pupae with blackish cephalothorax, failure of adult eclosion, and deformed abdomen and legs.

With regard to morphological abnormalities (Table 4), larval aberrations reached the highest values when treated with fenugreek oil ( $25 \%$ at $15 \mathrm{ppm})$. In the meanwhile, the morphological abnormalities were more pronounced in the pupal stage. It is evident that fenugreek and rocket oils caused the highest effect on the pupal stage, 55.5 and $50 \%$ at $62.5 \mathrm{ppm}$, respectively. At $250 \mathrm{ppm}$ of mustard and parsley, the pupal malformations were $40 \%$ and $50 \%$. Olibanum oil caused the highest

Table 1

Relative efficiency of the tested plant oils against $4^{\text {th }}$ larval instars of Culex pipiens, collected from Meit El-Attar, Qalyubia Governorate, Egypt

\begin{tabular}{|c|c|c|c|c|c|}
\hline Plant oils & LC 50 & LC 90 & LC90/LC50 & Slope function & Relative toxicity \\
\hline Fenugreek & 32.42 & 642.11 & 19.80 & $0.99 \pm 0.28$ & 4.72 \\
\hline Earth almond & 47.17 & 298.61 & 6.33 & $1.59 \pm 0.42$ & 3.24 \\
\hline Mustard & 71.37 & 353.84 & 4.96 & $1.84 \pm 0.26$ & 2.14 \\
\hline Olibanum & 83.36 & 1968.75 & 23.62 & $0.93 \pm 0.19$ & 1.83 \\
\hline Rocket & 86.06 & 1438.70 & 16.72 & $1.05 \pm 0.20$ & 1.48 \\
\hline Parsley & 152.94 & 2316.20 & 15.14 & $1.09 \pm 0.21$ & 1.00 \\
\hline
\end{tabular}

- Concentration (ppm, part per million) 
Table 2

The effect of the plant oils on some biological aspects after treatment of $4^{\text {th }}$ larval instars of Culex pipiens, collected from Meit El-Attar, Qalyubia Governorate, Egypt

\begin{tabular}{|c|c|c|c|c|}
\hline $\begin{array}{l}\text { Plant oils conc. } \\
(\mathrm{ppm})\end{array}$ & $\begin{array}{l}\text { Larval duration } \\
\text { (Days } \pm \mathrm{SE})\end{array}$ & $\begin{array}{l}\text { Pupal duration } \\
\text { (Days } \pm \text { SE) }\end{array}$ & $\begin{array}{l}\text { Pupation } \\
(\% \pm \mathrm{SE})\end{array}$ & $\begin{array}{c}\text { Emergence } \\
(\% \pm \mathrm{SE})\end{array}$ \\
\hline \multicolumn{5}{|l|}{ Fenugreek } \\
\hline 7.81 & $9.75 \pm 0.32^{\mathrm{a}}$ & $5.85 \pm 0.27^{\mathrm{a}}$ & $66.67 \pm 0.41^{b}$ & $87.10 \pm 0.63^{b}$ \\
\hline 15.63 & $7.38 \pm 0.29^{b}$ & $4.95 \pm 0.06^{\mathrm{b}}$ & $58.33 \pm 0.65^{\mathrm{c}}$ & $86.36 \pm 0.65^{\mathrm{c}}$ \\
\hline 31.25 & $5.48 \pm 0.25^{\mathrm{c}}$ & $3.99 \pm 0.08^{c}$ & $51.67 \pm 0.48^{\mathrm{d}}$ & $56.25 \pm 0.41^{\mathrm{d}}$ \\
\hline 62.50 & $5.14 \pm 0.12^{\mathrm{c}}$ & $3.05 \pm 0.13^{\mathrm{d}}$ & $33.33 \pm 0.41^{\mathrm{e}}$ & $42.86 \pm 0.48^{\mathrm{e}}$ \\
\hline 125 & $3.35 \pm 0.16^{\mathrm{d}}$ & $1.83 \pm 0.04^{\mathrm{f}}$ & $26.67 \pm 0.41^{\mathrm{f}}$ & $0.00 \pm 0.48^{\mathrm{f}}$ \\
\hline 500 & $1.0 \pm 0.03^{\mathrm{e}}$ & $0.83 \pm 0.04^{\mathrm{g}}$ & $11.67 \pm 0.47^{\mathrm{g}}$ & $0.00 \pm 0.29^{f}$ \\
\hline 1000 & $0.93 \pm 0.03^{\mathrm{e}}$ & $0.00 \pm 0.00^{\mathrm{h}}$ & $6.67 \pm 0.41^{\mathrm{h}}$ & $0.00 \pm 0.00^{\mathrm{f}}$ \\
\hline Control & $3.16 \pm 0.06^{\mathrm{d}}$ & $2.48 \pm 0.08^{\mathrm{e}}$ & $93.33 \pm 0.41^{\mathrm{a}}$ & $94.34 \pm 0.48^{\mathrm{a}}$ \\
\hline \multicolumn{5}{|l|}{ Earth almond } \\
\hline 15.63 & $6.71 \pm 0.24^{\mathrm{a}}$ & $0.75 \pm 0.06^{\mathrm{b}}$ & $76.67 \pm 0.65^{b}$ & $70.00 \pm 0.41^{\mathrm{d}}$ \\
\hline 31.25 & $6.66 \pm 0.06^{\mathrm{a}}$ & $0.82 \pm 0.04^{\mathrm{b}}$ & $60.00 \pm 0.41^{\mathrm{c}}$ & $85.71 \pm 0.41^{\mathrm{b}}$ \\
\hline 62.50 & $5.59 \pm 0.05^{\mathrm{b}}$ & $0.91 \pm 0.04^{b}$ & $41.67 \pm 0.25^{\mathrm{d}}$ & $84.21 \pm 0.48^{c}$ \\
\hline 125 & $3.50 \pm 0.10^{c}$ & $0.50 \pm 0.04^{c}$ & $23.33 \pm 0.65^{\mathrm{e}}$ & $0.00 \pm 0.29^{\mathrm{e}}$ \\
\hline 250 & $1.12 \pm 0.02^{\mathrm{d}}$ & $0.00 \pm 0.00^{\mathrm{d}}$ & $11.67 \pm 0.25^{\mathrm{f}}$ & $0.00 \pm 0.25^{\mathrm{e}}$ \\
\hline 500 & $1.28 \pm 0.16^{\mathrm{d}}$ & $0.00 \pm 0.00^{\mathrm{d}}$ & $5.00 \pm 0.25^{\mathrm{g}}$ & $0.00 \pm 0.00^{\mathrm{e}}$ \\
\hline Control & $4.00 \pm 0.41^{\mathrm{c}}$ & $2.05 \pm 0.13^{\mathrm{a}}$ & $98.33 \pm 0.48^{a}$ & $96.55 \pm 0.65^{\mathrm{a}}$ \\
\hline \multicolumn{5}{|l|}{ Mustard } \\
\hline 62.5 & $3.66 \pm 0.1^{\mathrm{a}}$ & $1.75 \pm 0.06^{\mathrm{b}}$ & $56.67 \pm 0.65^{b}$ & $55.56 \pm 0.65^{\mathrm{c}}$ \\
\hline 125 & $3.47 \pm 0.11^{\mathrm{a}}$ & $1.44 \pm 0.02^{\mathrm{c}}$ & $26.67 \pm 0.42^{\mathrm{c}}$ & $66.67 \pm 0.65^{b}$ \\
\hline 250 & $2.57 \pm 0.16^{\mathrm{b}}$ & $1.31 \pm 0.06^{\mathrm{d}}$ & $16.67 \pm 0.65^{\mathrm{d}}$ & $50.00 \pm 0.41^{\mathrm{d}}$ \\
\hline 500 & $2.56 \pm 0.06^{\mathrm{b}}$ & $1.24 \pm 0.04^{\mathrm{d}}$ & $6.67 \pm 0.41^{\mathrm{e}}$ & $0.00 \pm 0.25^{\mathrm{e}}$ \\
\hline 1000 & $2.10 \pm 0.04^{\mathrm{c}}$ & $0.70 \pm 0.20^{\mathrm{e}}$ & $1.67 \pm 0.25^{\mathrm{f}}$ & $0.00 \pm 0.00^{\mathrm{e}}$ \\
\hline Control & $3.93 \pm 0.15^{\mathrm{a}}$ & $2.05 \pm 0.13^{\mathrm{a}}$ & $98.33 \pm 0.63^{\mathrm{a}}$ & $98.25 \pm 0.75^{\mathrm{a}}$ \\
\hline
\end{tabular}

- Conc. (ppm) means concentration (part per million). - Mean within column followed by the same letter are not Significantly different (p $>0.05$, Duncan's multiple range test).

effect on the adult stage, $21.43 \%$ at 31.25 ppm. Accordingly, Fenugreek oil was the foremost cause of deformation in both larval and pupal stages.

\section{DISCUSSION}

In Egypt, resistance of $C$. pipiens to insecticides was reported in three filariasis-endemic areas of Egypt, as larval bioassay results showed clear indications of resistance to organophosphate insecticides and adult bioassays also showed widespread resistance to many insecticides related to organochlorine (OC), pyrethroid, organophosphate, and carbamate insecticides ${ }^{27}$. Additionally, larvae of $C$. pipiens were resistant to bacterial agent Bacillus thuringiensis var. israelensis in the laboratory ${ }^{18}$.

In the past few years, some plant compounds were investigated by several authors for anti-mosquito potential, including oviposition avoidance $^{25}$, larvicidal ${ }^{10,12,17}$, adulticidal ${ }^{4}$, and repellent activities ${ }^{4,16}$.

Fortunately, botanical insecticides are biodegradable and harmless to the environment ${ }^{11}$, pest-specific, and relatively harmless to non- target organisms and humans $\mathbf{s}^{20,22,23}$.

In this study, the used oils showed high toxic effect against larvae C. pipiens, especially, fenugreek, earth almond, mustard, and olibanum.

Pertaining to the prospective of botanical extracts as mosquito larvicides, fenugreek showed mosquito larvicidal activity against $C$. pipiens,
LC50 of chloroform extract of fenugreek was $234.05 \mathrm{ppm}^{10}$. Fenugreek was also toxic to stored product pests, Tribolium castaneum and Acanthoscelides obtectus ${ }^{15}$ and the cotton leaf worm Spodoptera littoralis ${ }^{10}$.

Fenugreek seeds induced oviposition avoidance or deterrence to gravid Aedes aegypti ${ }^{25}$. Also, mustard repelled vectors of Japanese encephalitis, C. pseudovishnui and C. gelidus ${ }^{16}$. Furthermore, the herbal repellents, Zanthoxylum limonella and Citrus aurantiifolia exhibited better protection against bites of Aedes albopictus in mustard oil than in coconut oil ${ }^{6}$.

Sesame, Sesamum indicum, nigella, Nigella sativa, and onion, Allium cepa, oils were highly toxic to C. pipiens ${ }^{12}$. On the other hand, sublethal doses of azadirachtin, extracted from neem, inhibited larval growth in C. tarsalis and C. quinquefasciatus ${ }^{22}$. Besides, ethanolic extract form Ginkgo biloba L. exocarp from the Chinese ginkgo was highly toxic against three strains of $C$. pipiens ${ }^{23}$. Additionally, crude seed extract of celery (Apium graveolens) possessed larvicidal, adulticidal, and repellent activities against Ae. aegypti ${ }^{4}$.

Methanolic extracts of the leaves of Atlantia monophylla were effective as mosquitocide against immature stages of three mosquito species, C. quinquefasciatus, Anopheles stephensi, and Ae. aegypti in the laboratory, such plant exhibit insect regulating activity ${ }^{20}$.

Regarding the morphological abnormalities, several authors 


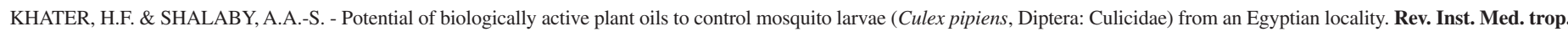
S. Paulo, 50(2): 107-112, 2008.

Table 3

The effect of the plant oils on some biological aspects after treatment of $4^{\text {th }}$ larval instars of Culex pipiens, collected from Meit El-Attar, Qalyubia Governorate, Egypt

\begin{tabular}{|c|c|c|c|c|}
\hline $\begin{array}{l}\text { Plant oils conc. } \\
(\mathrm{ppm})\end{array}$ & $\begin{array}{l}\text { Larval duration } \\
\text { (Days } \pm \mathrm{SE})\end{array}$ & $\begin{array}{l}\text { Pupal duration } \\
\text { (Days } \pm \text { SE) }\end{array}$ & $\begin{array}{l}\text { Pupation } \\
(\% \pm \mathrm{SE})\end{array}$ & $\begin{array}{c}\text { Emergence } \\
(\% \pm \mathrm{SE})\end{array}$ \\
\hline \multicolumn{5}{|l|}{ Rocket } \\
\hline 62.5 & $3.56 \pm 0.03^{\mathrm{a}}$ & $2.61 \pm 0.18^{\mathrm{a}}$ & $50.00 \pm 0.65^{\mathrm{b}}$ & $83.33 \pm 0.40^{\mathrm{b}}$ \\
\hline 125 & $2.79 \pm 0.02^{b}$ & $2.59 \pm 0.09^{a}$ & $40.00 \pm 0.40^{c}$ & $66.67 \pm 0.25^{c}$ \\
\hline 250 & $2.72 \pm 0.04^{b}$ & $2.47 \pm 0.6^{\mathrm{a}}$ & $33.33 \pm 0.29^{\mathrm{d}}$ & $33.33 \pm 0.29^{d}$ \\
\hline 500 & $2.34 \pm 0.07^{c}$ & $2.30 \pm 0.21^{\mathrm{a}}$ & $26.67 \pm 0.41^{\mathrm{e}}$ & $0.00 \pm 0.20^{\mathrm{e}}$ \\
\hline 1000 & $1.88 \pm 0.02^{\mathrm{d}}$ & $1.10 \pm 0.04^{b}$ & $6.67 \pm 0.41^{\mathrm{f}}$ & $0.00 \pm 0.00^{\mathrm{e}}$ \\
\hline Control & $3.67 \pm 0.04^{\mathrm{a}}$ & $2.36 \pm 0.06^{\mathrm{a}}$ & $95.00 \pm 0.63^{\mathrm{a}}$ & $100 \pm 0.75^{\mathrm{a}}$ \\
\hline \multicolumn{5}{|l|}{ Parsley } \\
\hline 125 & $2.89 \pm 0.24^{b}$ & $1.38 \pm 0.12^{\mathrm{d}}$ & $43.33 \pm 0.65^{b}$ & $80.00 \pm 0.65^{b}$ \\
\hline 250 & $2.92 \pm 0.04^{\mathrm{b}}$ & $2.02 \pm 0.04^{\mathrm{c}}$ & $40.00 \pm 0.00^{c}$ & $00.00 \pm 0.41^{\mathrm{c}}$ \\
\hline 500 & $2.76 \pm 0.06^{\mathrm{b}}$ & $2.14 \pm 4.62^{c}$ & $33.33 \pm 0.41^{\mathrm{d}}$ & $0.00 \pm 0.29^{c}$ \\
\hline 1000 & $2.82 \pm 0.04^{b}$ & $3.46 \pm 0.20^{\mathrm{a}}$ & $23.33 \pm 0.65^{\mathrm{e}}$ & $0.00 \pm 0.00^{c}$ \\
\hline 2000 & $1.04 \pm 0.02^{\mathrm{c}}$ & $3.42 \pm 0.20^{\mathrm{a}}$ & $3.33 \pm 0.29^{f}$ & $0.00 \pm 0.00^{c}$ \\
\hline Control & $3.43 \pm 0.08^{\mathrm{a}}$ & $2.64 \pm 0.11^{\mathrm{b}}$ & $93.33 \pm 0.71^{\mathrm{a}}$ & $100.00 \pm 0.65^{\mathrm{a}}$ \\
\hline \multicolumn{5}{|l|}{ Olibanum } \\
\hline 7.81 & $14.90 \pm 0.33^{\mathrm{a}}$ & $8.25 \pm 0.32^{\mathrm{a}}$ & $83.33 \pm 0.65^{b}$ & $69.57 \pm 0.65^{b}$ \\
\hline 31.25 & $11.38 \pm 0.24^{\mathrm{b}}$ & $5.17 \pm 0.15^{\mathrm{b}}$ & $53.33 \pm 0.41^{c}$ & $64.29 \pm 0.41^{c}$ \\
\hline 62.50 & $9.13 \pm 0.18^{c}$ & $4.18 \pm 0.13^{c}$ & $46.67 \pm 0.71^{\mathrm{d}}$ & $56.52 \pm 0.48^{\mathrm{e}}$ \\
\hline 250 & $8.29 \pm 0.33^{\mathrm{d}}$ & $3.84 \pm 0.14^{\mathrm{c}}$ & $30.00 \pm 0.65^{\mathrm{e}}$ & $62.50 \pm 0.41^{\mathrm{d}}$ \\
\hline 500 & $4.53 \pm 0.21^{\mathrm{e}}$ & $2.53 \pm 0.19^{\mathrm{d}}$ & $23.33 \pm 0.29^{f}$ & $0.00 \pm 0.25^{\mathrm{f}}$ \\
\hline 1000 & $1.79 \pm 0.46^{\mathrm{g}}$ & $1.55 \pm 0.19^{\mathrm{e}}$ & $15.00 \pm 0.25^{\mathrm{g}}$ & $0.00 \pm 0.25^{\mathrm{f}}$ \\
\hline 2000 & $1.05 \pm 0.08^{\mathrm{g}}$ & $0.00 \pm 0.00^{\mathrm{f}}$ & $8.33 \pm 0.25^{\mathrm{h}}$ & $0.00 \pm 0.00^{f}$ \\
\hline Control & $3.39 \pm 0.14^{\mathrm{f}}$ & $2.25 \pm 0.09^{\mathrm{d}}$ & $91.67 \pm 0.65^{\mathrm{a}}$ & $94.34 \pm 0.48^{\mathrm{a}}$ \\
\hline
\end{tabular}

- Conc. (ppm) means concentration (part per million); - Mean within column followed by the same letter are not significantly different ( $p>0.05$, Duncan's multiple range test)

Table 4

Percentage of larval, pupal, and adult morphological abnormalities observed after treatment of $4^{\text {th }}$ larval instars of Culex pipiens with plant oils

\begin{tabular}{|c|c|c|c|c|c|c|c|}
\hline Plant oils conc. (ppm) & Larvae & Pupae & Adults & Plant oils conc. (ppm) & Larvae & Pupae & Adults \\
\hline Fenugreek & & & & Olibanum & & & \\
\hline 7.81 & 12.67 & 22.5 & 6.45 & 7.81 & 5.00 & 8.00 & 19.57 \\
\hline 15.63 & 25.00 & 37.14 & 4.54 & 31.25 & 8.33 & 9.38 & 21.43 \\
\hline 31.25 & 21.67 & 45.16 & 6.25 & 62.5 & 6.67 & 10.71 & 13.04 \\
\hline 62.5 & 16.67 & 55.00 & 0.00 & 250 & 11.67 & 55.56 & 12.50 \\
\hline 125 & 8.33 & 0.00 & 0.00 & 500 & 0.00 & 0.00 & 0.00 \\
\hline 500 & 0.00 & 0.00 & 0.00 & 1000 & 0.00 & 0.00 & 0.00 \\
\hline 1000 & 0.00 & 0.00 & 0.00 & 2000 & 0.00 & 0.00 & 0.00 \\
\hline Control & 0.00 & 0.00 & 0.00 & Control & 0.00 & 0.00 & 0.00 \\
\hline Earth almond & & & & Rocket & & & \\
\hline 15.63 & 8.33 & 13.04 & 10 & 62.5 & 8.33 & 50 & 8.33 \\
\hline 31.25 & 5.00 & 16.67 & 3.57 & 125 & 3.33 & 16.67 & 11.11 \\
\hline 62.5 & 5.00 & 20.00 & 0.00 & 250 & 3.33 & 30.00 & 16.67 \\
\hline 125 & 3.33 & 0.00 & 0.00 & 500 & 1.67 & 6.25 & 0.00 \\
\hline 250 & 0.00 & 0.00 & 0.00 & 1000 & 1.67 & 25.00 & 0.00 \\
\hline 500 & 0.00 & 0.00 & 0.00 & Control & 0.00 & 0.00 & 0.00 \\
\hline Control & 0.00 & 0.00 & 0.00 & & & & \\
\hline Mustard & & & & Parsley & & & \\
\hline 62.5 & 1.67 & 11.77 & 5.56 & 125 & 10 & 38.46 & 10.00 \\
\hline 125 & 3.33 & 31.25 & 16.67 & 250 & 6.67 & 50.00 & 0.00 \\
\hline 250 & 6.67 & 40.00 & 0.00 & 500 & 16.67 & 60.00 & 0.00 \\
\hline 500 & 0.00 & 0.00 & 0.00 & 1000 & 0.00 & 50.00 & 0.00 \\
\hline 1000 & 0.00 & 0.00 & 0.00 & 2000 & 0.00 & 0.00 & 0.00 \\
\hline Control & 0.00 & 0.00 & 0.00 & Control & 0.00 & 0.00 & 0.00 \\
\hline
\end{tabular}

Conc. (ppm) means concentration (part per million) 
recorded similar anomalies, when applied different plant extracts at sublethal concentrations. Pigmented larvae and pharate pupae were reported after treatment with sesame oil ${ }^{12}$. Albino pupae were recounted after treatment with neem seed kernel extract ${ }^{7}$ and nigella oil ${ }^{12}$. Blackish cephalothoraxes were observed after treatment with fenugreek ${ }^{10}$ and onion oil ${ }^{12}$. Finally, failure of adult eclosion as well as deformed abdomen and legs were recorded after treatment with fenugreek ${ }^{10}$, sesame, nigella and onion oils ${ }^{12}$, and garlic ${ }^{17}$.

Concerning abnormally percentage, comparable results were recorded against $C$. pipiens following treatment with fenugreek ${ }^{10}$ and onion $^{12}$.

These results indicated a metamorphosis inhibiting effect of the plant oils, which possibly based on the disturbance of hormonal control ${ }^{2}$, as the noticed morphogenetic aberrations suggesting a type of insect growth regulating activity. The most important deformities, larval-pupal intermediates and ecdysal failure, seemed to be the major cause of the mortalities. Likewise, such abnormalities were noted following treatment of immature mosquitoes with juvenile hormone $(\mathrm{JH})$ analogues and chitin synthesis inhibitors ${ }^{8,12,20}$.

With reference to biological aspects, the data revealed prolongation of the larval developmental periods, following treatment with sublethal concentrations of olibanum and fenugreek, 14.9 and 8.2 days, respectively. Similar results were recorded after treatment of $C$. pipiens with onion, sesame, and nigella oils, 12.6, 9.3, and 8.5 days, respectively ${ }^{12}$, and ethanolic extract of fenugreek, 18.02 days $^{10}$. Likewise, white and black mustard lengthened the duration of $2^{\text {nd }}$ larval instars of Musca domestica ${ }^{1}$.

Comparable prolongations of pupal developmental periods were also recorded ${ }^{1,17,24}$, although HALAWA ${ }^{10}$ reported that fenugreek decreased the pupal durations of $C$. pipiens and S. littoralis. Such result was similar to that reported by earth almond and mustard oils.

The prolongation of developmental periods occurred because plant extracts had insect growth regulating activity, which may inhibit insect development ${ }^{12,14,20}$.

Similar reduction in the pupation rates and adult emergences, following exposure to higher concentrations of several plant extracts were reported after treatment of $C$. pipiens with different plant extracts, such as: neem seed kernel extract ${ }^{7}$, fenugreek ${ }^{10}$, and nigella, onion, and sesame oils ${ }^{12}$.

Likewise, the pupation rates and adult emergence were affected after exposure of Ae. aegypti to yellow rocket and black mustard ${ }^{24}$, and M. domestica to white and black mustard ${ }^{1}$.

Additionally, topical application of fenugreek was detrimental to stored product pests, T. castaneum and A. obtectus causing high degree of mortalities, inhibited ovipositing, and larval penetration, together with decreased fecundity, fertility, and longevity ${ }^{15}$.

\section{CONCLUSION}

The activity of the larvicidal oils extends beyond the larval stages, subsequently, these oils killed C. pipiens larvae at higher concentrations, but when diluted, they caused a series of morphological problems that inhibit larvae to complete metamorphosis. Consequently, the applied oils could be classified as insect growth regulators.

Before field application, the safety of the applied oils to human and the environment must be investigated, and the oils should be tested on some populations with alteration on insecticide susceptibility to different compounds. After that, the readily available plant oils may lead to future development of botanical insecticide that could be integrated into other pest management programs for control of mosquitoes primarily in the developing countries

\section{RESUMO}

\section{Potencial de óleos de plantas biologicamente ativos para o controle da larva do mosquito Culex pipiens (Diptera: Culicidae) de localidade egípcia}

O efeito inseticida de seis óleos de plantas comercialmente disponíveis foi testado contra larvas de $4^{\circ}$ instar de Culex pipiens. Larvas foram coletadas originalmente de Meit El-Attar, Qalyubia Governorate, Egito e então cultivadas no laboratório até a geração $\mathrm{F}_{1}$. Os valores LC50 foram 32,42, 47,17, 71,37, 83,36, 86,06 e 152,94 ppm para o feno grego (Trigonella foenum-grecum), amêndoa da terra (Cyperus esculentus), mostarda (Brassica compestris), olíbano (Boswellia serrata), rocket (Eruca sativa) e salsa (Carum ptroselium), respectivamente. Os óleos testados alteraram alguns aspectos biológicos do $C$. pipiens, por exemplo os períodos de desenvolvimento, estados de crisálida, e emergências de adultos. As concentrações mais baixas de óleo de olíbano e feno grego causaram extraordinário prolongamento da duração larval e pupal. Dados também mostraram que o aumento das concentrações foi diretamente proporcional à redução no estado de crisálida e emergências dos adultos. Notável decréscimo no estado de crisálida foi conseguido com o óleo de mostarda a 1000 ppm. Emergência de adulto foi diminuída no óleo de amêndoa da terra e feno grego a 25 ppm. Além do mais, os óleos de plantas testados, exibiram várias anormalidades morfológicas nas larvas, pupas e estádios adultos. Consequentemente, o óleo de feno grego foi o óleo mais potente e o maior causador de malformação em ambos estádios larval e pupal. Potencial dos óleos de plantas aplicados mostraram excelente resultado no controle do $C$. pipiens.

\section{ACKNOWLEDGMENTS}

The author would like to show gratitude to Dr. Nagwa Ahmed, Parasitology Department, Faculty of Veterinary Medicine, Benha University, Egypt, as well as Dr. Aza Moustafa, Research Institute of Medical Entomology, Egypt, for their support and suggestions.

\section{REFERENCES}

1. ABDEL-KADDER, A. - Toxicological and histopathological effects of some botanical extracts on the house fly Musca domestica L. 2005. (Ph.D Thesis - Fac. Sci., Zool. Dept., El- Minia University).

2. AL-SHAROOK, Z.; BALAN, K.; JIANG, Y. \& REMBOLD, H. - Insect growth inhibitors from tropical Meliaceae effect of crude extracts on mosquito larvae. J. appl. Entomol., III: 425-430, 1991 
3. CASIMIRO, S.; COLEMAN, M.; MOHLOAI P.; HEMINGWAY, J. \& SHARP, B. Insecticide resistance in Anopheles funestus (Diptera: Culicidae) from Mozambique. J. med. Entomol., 43: 267-275, 2006.

4. CHOOCHOTE, W.; TUETUN, B.; KANJANAPOTHI, D. et al. - Potential of crud seed extract of celery, Apium graveolens L., against the mosquito Aedes aegypti (L.) (Diptera: Culicidae). J. vector Ecol., 29: 340-346, 2004.

5. DARWISH, M. \& HOOGSTRAAL, H. - Arboviruses infesting human and lower animals in Egypt. A review of the thirty years of research. J. Egypt. publ. Hlth Ass., 56: 1112,1981

6. DAS, N.G.; BARUAH, I.; TALUKDAR, P.K. \& DAS, S.C. - Evaluation of botanicals as repellents against mosquitoes. J. vector Borne Dis., 40: 49-53, 2003.

7. DESOKY, E.A. - Possibilities of mosquito control by using neem seed kernel extracts (Azadirachta indica A. Juss). Alex. J. vet. Sci., 11: 101-104, 1995.

8. EL-BARKY, N.M. - Effect of some insect growth regulators on Culex pipiens in Qalyubia Governorate. 1993. (M. Sc. Thesis - Fac. Sci. Zagazig Univ., Benha Branch).

9. FINNEY, D.J. - Probit analysis: a statistical treatment of sigmoid response curve. Cambridge, University Press, 1971.

10. HALAWA, S.M. - Studies on the use of some plant extracts as factors in pest management. 2001. (Ph.D Thesis - Faculty of Agriculture, Moshtohor Zagazig University, Benha Branch).

11. JACOBSON, M. - Insecticides from plants: a review of the literature, agricultural handbook. Washington, U.S. Dep. Agriculture, 1975. v. 138, p. 1954-1971.

12. KHATER, H.F. - Biocontrol of some insects. 2003. (Ph.D Thesis - Fac. Vet. Med., Moshtohor, Zagazig Univ. Benha Branch).

13. LIU, H.; XU, Q.; ZHANG, L. \& LIU, N. - Chlorpyrifos resistance in mosquito Culex quinquefasciatus. J. med. Entomol., 42: 815-820, 2005.

14. MOHSEN, Z.H.; JAWAD, A.L.M.; AL-CHALABI, B.M. \& AL-NAIB, A. - Biological activity of callistemon. Lanceolatus against Culex quinquefasciatus. Fitoterapia, 61: $270-274,1990$.

15. PEMONGE, J.; PASCUAL, V.M.J \& REGNNAULT, R.C. - Effect of material and extract of Trigonella foenum-grecum L. against the stored product pests Tribolium castaneum (Coleoptera: Tenebrionidae) and Acanthoscelides obtectus (Say) Coleoptera: Bruchidae). J. stored prod. Resol., 33: 209-217, 1997.

16. PRAKASH, A.; BHATTACHARYA, D.R.; MOPHAPATRA, P.K. \& MAHANTA, J. Preliminary field evolution of repellent action of neem oil in Assam against two mosquito vectors of Japanese encephalitis. J. paras. Dis., 24: 221-222, 2000.
17. SALEH, E.H. - Effect of some botanical extracts as potential insecticides for the control of some mosquitoes in Egypt. 1995. (Ph. D. degree - Dep. Entomol. Fac. Sci. Cairo Univ., Egypt).

18. SALEH, M.S.; EL-MENIAWI, F.A.; KELADA, N.L. \& ZAHRAN, H.M. - Resistance development in mosquito larvae Culex pipiens to the bacterial agent Bacillus thuringiensis var. israelensis. J. appl. Entomol., 127, 29-32, 2003.

19. SHALABY, A.A.; AL-LLAM, K.A.M. \& MOUSTAFA, A.A. - Toxicity evaluation of plant extracts on their combinations with a synthetic pyrethroid "Cyphenothrin" against larvae of Culex pipiens (Diptera: Culicidae). Egyp. J. med. Sci., 18: 199212, 1997.

20. SIVAGNANAME, N. \& KALYANASUNDARAM, M. - Laboratory evaluation of methanolic extract of Atlantia monophylla (Family: Rutaceae) against immature stages of mosquitoes and non-target organisms. Mem. Inst. Oswaldo Cruz, 99: 115-118, 2004.

21. SOUTHGATE, B.A. - Bancroftian filariasis in Egypt. Trop. Dis. Bull., 76: 1045-1066, 1979

22. SU, T. \& MULLA, M.S. - Ovicidal activity of neem products (azadirachtin) against Culex tarsalis and Culex quinquefasciatus (Diptera: Culicidae). J. Amer. Mosq. contr Ass., 14: 204-209, 1998.

23. SUN, L.; DONG, H.; GUO, C. et al. - Larvicidal activity of extracts of Ginkgo biloba exocarp for three different strains of Culex pipiens pallens. J. med. Entomol., 43: 258-261, 2006.

24. SUPAVARN, P.; KNAPP, F.W. \& SIGAFUS, R. - Biologically active plant extracts for control of mosquito larvae. Mosq. News, 34: 398-402, 1974.

25. TILAK, R.; GUPTA, M.V.; SURYAM, M.V.; YADAV, J.D. \& GUPTA, B.K. - A laboratory investigation into oviposition responses of Aedes aegypti to some common household substances and water from conspecific larvae. Med. J. Armed Forces India, 61: 227-229, 2005.

26. WORLD HEALTH ORGANIZATION (WHO) - Instructions for determining the susceptibility or resistance of mosquito larvae to insecticides. Geneva, WHO, 1981

27. ZAYED, A.B.; SZUMLAS, D.E.; HANAFI, A. et al. - Use of bioassay and microplate assay to detect and measure insecticide resistance in field populations of Culex pipiens from filariasis endemic areas of Egypt. J. Amer. Mosq. contr. Ass., 22: 473-482, 2006.

Received: 17 November 2006

Accepted: 30 November 2007 